\title{
Purinergic signaling gene network expression in bovine polymorphonuclear neutrophils during the peripartal period ${ }^{1}$
}

\author{
J. Seo, ${ }^{*} \dagger$ J. S. Osorio, $†$ and J. J. Loort ${ }^{2}$ \\ *Department of Agricultural Biotechnology, Research Institute for Agriculture and Life Sciences, College of Agriculture and Life Sciences, \\ Seoul National University, Daehak-dong, Kwanak-gu, Seoul 151-742, Republic of Korea \\ †Mammalian NutriPhysioGenomics, Department of Animal Sciences and Division of Nutritional Sciences, University of Illinois, \\ 1207 West Gregory Drive, Urbana 61801
}

\section{ABSTRACT}

An effective immune response relies on efficient activation of polymorphonuclear neutrophilic leukocytes (PMNL). The PMNL release cellular ATP in response to inflammatory mediators. Although extracellular ATP is rapidly degraded to adenosine, both compounds can readily bind to either the purinergic receptor $\mathrm{P} 1$ (adenosine) or P2 (ATP). The P1 and P2 receptors are members of the G-protein-coupled receptor family. The peripartal period is characterized by marked changes in metabolic and inflammatory status that are functionally related with immune responses in the cow. We evaluated the mRNA expression of genes associated with purinergic signaling in PMNL during the peripartal period. Seven multiparous Holstein cows were dried off at d -50 relative to expected parturition and fed a controlled-energy diet (net energy for lactation $=1.24 \mathrm{Mcal} / \mathrm{kg}$ of dry matter) for ad libitum intake during the entire dry period. After calving, all cows were fed a common lactation diet (net energy for lactation $=1.65 \mathrm{Mcal} / \mathrm{kg}$ of dry matter) until 30 $\mathrm{d}$ in milk. Blood PMNL collected at $-10,3$, and $21 \mathrm{~d}$ in milk were used to study the expression of 22 genes associated with adhesion to endothelium, chemoattractant binding at the plasma membrane, and purinergic signaling. Other blood samples around calving were used to analyze concentrations of insulin, metabolites, and whole-blood phagocytosis. The expression of purinergic receptor P2Y, G-protein coupled, 2 (P2RY2) increased on $\mathrm{d} 3$ and then decreased on $\mathrm{d}$ 21. This response suggested that ATP could play a role in the amplification of chemotactic signals. In contrast, the expression of genes encoding cell adhesion [selectin L (SELL) and selectin P ligand (SELPLG)], chemoattractant receptors [complement component

Received April 23, 2013.

Accepted August 14, 2013.

${ }^{1}$ Supported by Hatch funds under project ILLU-538-392 (National Institute of Food and Agriculture).

${ }^{2}$ Corresponding author: jloor@illinois.edu 5a receptor 1 (C5AR1), IL-8 receptor $\alpha$ (CXCR1), IL-8 receptor $\beta$ (CXCR2), and platelet-activating factor receptor $(P T A F R)]$, and adenosine receptors [adenosine $\mathrm{A} 1$ receptor $(A D O R A 1)$ and adenosine $\mathrm{A} 3$ receptor $(A D O R A 3)]$ decreased between -10 and 3 d. The decrease coincided with a marked increase in blood nonesterified fatty acids and hydroxybutyrate concentrations, and a decrease in glucose and insulin concentrations. The increase in metabolites also was associated with greater expression of leukotriene B4 receptor $(L T B 4 R)$ on d 3 and 21 compared with d -10 , which is involved in inflammatory prostaglandin synthesis. Most chemoattractant receptors increased by $21 \mathrm{~d}$, but cell adhesion genes and blood leukocyte phagocytosis was lower. The expression of adenosine A2a receptor $(A D O R A 2 A)$, which is associated with immunosuppression of PMNL and that of adenosine uptake channels [solute carrier family 29 (nucleoside transporters), member 1 (SLC29A1) and member 2 (SLC29A2)] and the nucleotidase adenosine deaminase $(A D A)$ was greater at 3 and $21 \mathrm{~d}$ compared with -10 d. The reduction in key immune responses, such as cell adhesion and chemotaxis, by bovine PMNL could partly be a function of changes in mRNA expression of genes associated with purinergic signaling.

Key words: inflammation, transition cow, adenosine, adenosine triphosphate

\section{INTRODUCTION}

Polymorphonuclear neutrophilic leukocyte chemotaxis is an important feature of the immune response to an invading pathogen (Amulic et al., 2012). At the level of PMNL, this process is partly regulated by extracellular nucleotides (e.g., ATP) and adenosine, which serve as intercellular messengers during the immune response (Chen et al., 2006; Chen et al., 2010). The PMNL release cellular ATP via pannexin 1 (PANX1) hemichannels upon activation (Chen et al., 2010). Once outside the cell, ATP has a half-life measured in seconds as a result of the action of several nucleotidases and hydrolytic enzymes causing the degradation of ATP to 
ADP, AMP, and adenosine (Picher et al., 2004). The ATP released into the extracellular space, and adenosine, can exert paracrine and autocrine effects that can regulate PMNL function partly via activation of purinergic receptors (Chen et al., 2010).

The purinergic receptors are classified into $\mathbf{P} \mathbf{1}$ (or ADORA) adenosine receptors and P2 (or P2RY) nucleotide receptors. Although both types of receptors share the overall topological structure that is typical of $\mathrm{G}$ protein-coupled receptors, it is now evident from sequencing analysis that $\mathrm{P} 1$ and $\mathrm{P} 2$ belong to 2 different groups of G protein-coupled receptors (D' Ambrosi and Volonte, 2013). These receptors are further subdivided into P2X (P2RX) and P2Y (P2RY) receptors. For instance, unlike P2X that work as ATP-gated ion channels, the P2Y encompass ATP, uridine triphosphate, and their related molecules (Chen et al., 2010).

The purinergic receptor P2Y, G-protein coupled, 2 (P2RY2) and adenosine A3 (ADORA3) receptors are considered the major purine receptors capable of stimulating chemotaxis by PMNL (Chen et al., 2006). In contrast, the adenosine A2 receptors (ADORA2) are involved in the inhibition of PMNL migration, recruitment to the infected cells, and adhesion and infiltration to the endothelium near infection sites (Barletta et al., 2012). The existence of nucleotide-hydrolyzing enzymes [e.g., adenosine deaminase (ADA)] also is an important factor in the context of PMNL chemotaxis because such enzymes can modulate the concentration of ATP and adenosine, thereby affecting PMNL chemotaxis (Junger, 2011).

The PMNL account for up to $70 \%$ of leukocytes in humans (Junger, 2008) and a review of the literature concluded that in bovine, the PMNL account, on average, for only $25 \%$ of leukocytes (Paape et al., 2003). However, instances exist when the PMNL become a more predominant component of leukocytes [e.g., during an inflammatory challenge (adrenocorticotropin), the PMNL accounted for up to $60 \%$ of leukocytes (Paape et al., 1974)], and also around parturition, the number of PMNL increases before calving and decreases soon after calving (Kimura et al., 1999). A recent study reported that PMNL accounted for 54 to $69 \%$ of total leukocytes on $\mathrm{d}-30$ prepartum and at calving (Trevisi et al., 2010). The pattern of change in PMNL around calving was proposed to represent a compensatory effect due to the inherently lower phagocytic capacity of PMNL during this physiological stage (Ingvartsen et al., 2003). However, recent data provided evidence that overall PMNL phagocytic performance after calving is not always lower than that prepartum (Sander et al., 2011).

Several studies reported that both the innate and adaptive immune systems in peripartal cows are often compromised; for example, cytokine production is impaired (Sordillo and Babiuk, 1991; Ishikawa et al., 1994), oxidative burst activity is reduced (Dosogne et al., 1999), and consequently phagocytic activity by leukocytes is often (Ingvartsen et al., 2003), but not always (Sander et al., 2011; Graugnard et al., 2012), reduced. Those functional changes are often accompanied by alterations in PMNL gene expression patterns (Preisler et al., 2000; Madsen et al., 2004). However, to our knowledge, no information exists regarding the purinergic signaling network in PMNL or whether the pattern of expression is altered around parturition. We hypothesized that purinergic signaling gene networks in PMNL are altered during the periparturient period. Our objective was to investigate not only the mRNA expression of genes in the pathway but also genes related to adhesion and migration of PMNL.

\section{MATERIALS AND METHODS}

\section{Animals and Management}

Complete details of these procedures were previously reported by Ji et al. (2012). Briefly, 7 multiparous Holstein cows were used. All cows were dried off at d -50 relative to expected parturition and fed a controlledenergy diet $\left(\mathrm{NE}_{\mathrm{L}}=1.24 \mathrm{Mcal} / \mathrm{kg}\right.$ of $\left.\mathrm{DM}\right)$ containing wheat straw at $36 \%$ of DM for ad libitum intake for the entire dry period. After calving, all cows were fed a common lactation diet $\left(\mathrm{NE}_{\mathrm{L}}=1.65 \mathrm{Mcal} / \mathrm{kg}\right.$ of $\left.\mathrm{DM}\right)$ until 30 DIM. Blood was sampled from the coccygeal vein or artery every Monday and Thursday before the morning feeding from -26 to $30 \mathrm{~d}$ around parturition. Samples were collected into evacuated serum tubes containing clot activator (BD Vacutainer; BD and Co., Franklin Lakes, NJ). Serum was obtained by centrifugation at $1,300 \times g$ for $15 \mathrm{~min}$ at $4^{\circ} \mathrm{C}$ and frozen at $-20^{\circ} \mathrm{C}$ until later analysis.

\section{Whole-Blood Phagocytosis}

The phagocytic capacity of leukocytes in heparinized whole blood was determined using the Phagotest kit (Orpegen Pharma, Heidelberg, Germany; Ballou, 2012). In brief, $20 \mu \mathrm{L}$ of bacteria Escherichia coli was added to 1 of 3 whole-blood samples $(100 \mu \mathrm{L})$ in test tubes (Falcon; Becton Dickinson, Franklin Lakes, NJ) and incubated for $10 \mathrm{~min}$ at $37^{\circ} \mathrm{C}$. The cells were resuspended in $200 \mu \mathrm{L}$ of DNA-staining solution, and light-protected in an ice bath until analyzed by flow cytometry (LSR II; Becton Dickinson, San Jose, CA).

\section{Isolation of PMNL}

Neutrophils were isolated based on procedures described by Moyes et al. (2010), with modifications. 
Briefly, blood collected at $-10,3$, and $21 \mathrm{~d}$ in acid citrate dextrose (ACD) Vacutainer tubes (BD and Co.) was mixed well by inversion and placed on ice until isolation. Samples were centrifuged at $600 \times g$ for 30 $\min$ at $4^{\circ} \mathrm{C}$. The plasma, buffy coat, and approximately one-third of the red blood cells were removed and discarded. The remaining sample was poured into a $50-\mathrm{mL}$ conical tube (Fisher Scientific, Pittsburgh, PA). Twenty-five milliliters of deionized water at $4^{\circ} \mathrm{C}$ was added to lyse red blood cells; this was followed by addition of $5 \mathrm{~mL}$ of $5 \times$ PBS (without calcium and magnesium) at $4^{\circ} \mathrm{C}$ to restore an isosmotic environment. Samples were centrifuged at $200 \times \mathrm{g}$ for $10 \mathrm{~min}$ at $4^{\circ} \mathrm{C}$, and the supernatants were decanted. The pellet was washed with $10 \mathrm{~mL}$ of $1 \times$ PBS and centrifuged for 5 min $(200$ $\times g$ at $4^{\circ} \mathrm{C}$ ), and the supernatant was decanted. Eight milliliters of deionized water at $4^{\circ} \mathrm{C}$ was added; this was followed by addition of $2 \mathrm{~mL}$ of $5 \times \mathrm{PBS}$ at $4^{\circ} \mathrm{C}$. Samples were centrifuged at $500 \times g$ for 5 min at $4^{\circ} \mathrm{C}$ and the supernatant was decanted. Two subsequent washings using $10 \mathrm{~mL}$ of $1 \times \mathrm{PBS}$ at $4^{\circ} \mathrm{C}$ were performed with samples centrifuged at $500 \times g$ for $5 \mathrm{~min}$ at $4^{\circ} \mathrm{C}$ and the supernatant was decanted. The average viability of PMNL evaluated using trypan blue was $82 \%$ and the average content of PMNL analyzed via cell differential was $73 \%$. Neutrophils were immediately homogenized in $2 \mathrm{~mL}$ of TRIzol reagent (Invitrogen Corp., Carlsbad, CA) with $1 \mu \mathrm{L}$ of linear acrylamide (Ambion, Inc., Austin, TX) using a Polytron power homogenizer at maximum speed. The suspension was transferred equally into 2 RNA-free microcentrifuge tubes (2 mL; Fisher Scientific, Pittsburgh, PA) and stored at $-80^{\circ} \mathrm{C}$ until further analysis. The quality of RNA evaluated via RNA integrity number (RIN) in the 2100 Bioanalyzer (Agilent Technologies Inc., Santa Clara, CA) was $7.0 \pm 0.2$.

\section{Quantitative Reverse-Transcription PCR}

Specific details of RNA isolation from PMNL, primer design, evaluation, and real-time quantitative PCR are presented in the Supplemental Materials (available online at http://dx.doi.org/10.3168/jds.2013-6952). Briefly, we used 3 genes [golgin subfamily A, member 5 (GOLGA5), oxysterol-binding protein-like 2 (OSBPL2), and single-strand-selective monofunctional uracil-DNA glycosylase 1 (SMUG1); Moyes et al., 2010] previously verified as suitable for PMNL as internal control genes. Target genes were normalized with the geometric mean of the 3 internal control genes. Percentage relative abundance of each mRNA was calculated to provide additional mechanistic information on the target genes (Bionaz and Loor, 2008).

\section{Statistical Analysis}

The gene expression and blood data were analyzed with PROC MIXED of SAS (version 9.2; SAS Institute Inc., Cary, NC). The fixed effect in the model was time. The random effect was cow. Least squares means separation between time points was performed using the PDIFF statement. Significance was declared at $P$ $<0.05$.

\section{RESULTS}

\section{Blood Insulin, Metabolites, and Leukocyte Phagocytosis}

As expected, the concentration of NEFA and BHBA increased markedly after calving, and the concentration of insulin and glucose decreased (Figure 1). Although no change $(P>0.05)$ was observed between -10 and $3 \mathrm{~d}$ in percentage phagocytosis by whole-blood leukocytes, it decreased on d 21 to levels below d -10 and 3 (Figure 2).

\section{Cell Adhesion and Transmigration}

As shown in Table 1, the expression of $\beta 2$ integrin (ITGB2) after parturition did not differ compared with d -10 . The expression of selectin L $(\boldsymbol{S E \boldsymbol { L } L})$, selectin

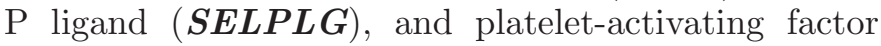
receptor $(P T A F R)$ was lower $(P<0.01)$ at $\mathrm{d} 3$ and 21 compared with $\mathrm{d}-10$ (Figure 3 ). The lowest $(P$ $<0.01$ ) expression of the complement component $5 \mathrm{a}$ receptor 1 (C5AR1), and IL-8 receptors $\alpha(C X C R 1)$ and $\beta$ (CXCR2) was observed at $\mathrm{d} 3$ than other time points (Table 1). However, the expression of leukotriene B4 receptor $(L T B 4 R)$ was drastically upregulated $(P$ $<0.01$ ) at d 3 and 21 compared with d -10 (Table 1 ).

\section{Purinergic Receptors}

The expression of adenosine A2a receptor $(\boldsymbol{A D O R A 2 A})$ increased $(P<0.01)$ on d 3 compared with $\mathrm{d}-10$ and then decreased on d 21 (Figure 4), whereas the expression of adenosine A1 receptor (ADORA1) and adenosine A3 receptor (ADORA3) decreased $(P<0.01)$ from $\mathrm{d}-10$ to 3 and then increased to prepartal levels on d 21 (Figure 4). The mRNA expression of P2X ligand-gated ion channel, 7 $\left(\boldsymbol{P} 2 \boldsymbol{R} \boldsymbol{X}^{\boldsymbol{\gamma}}\right)$ also was upregulated $(P<0.01)$ at $\mathrm{d} 3$ and 21 compared with d -10 , similar to ADORA2A, but expression of P2RY2 and purinergic receptor P2Y Gprotein coupled, 11 (P2RY11) was higher $(P=0.02$ and $P<0.01$ respectively) only at d 3 compared with $\mathrm{d}-10$ and 21 . 

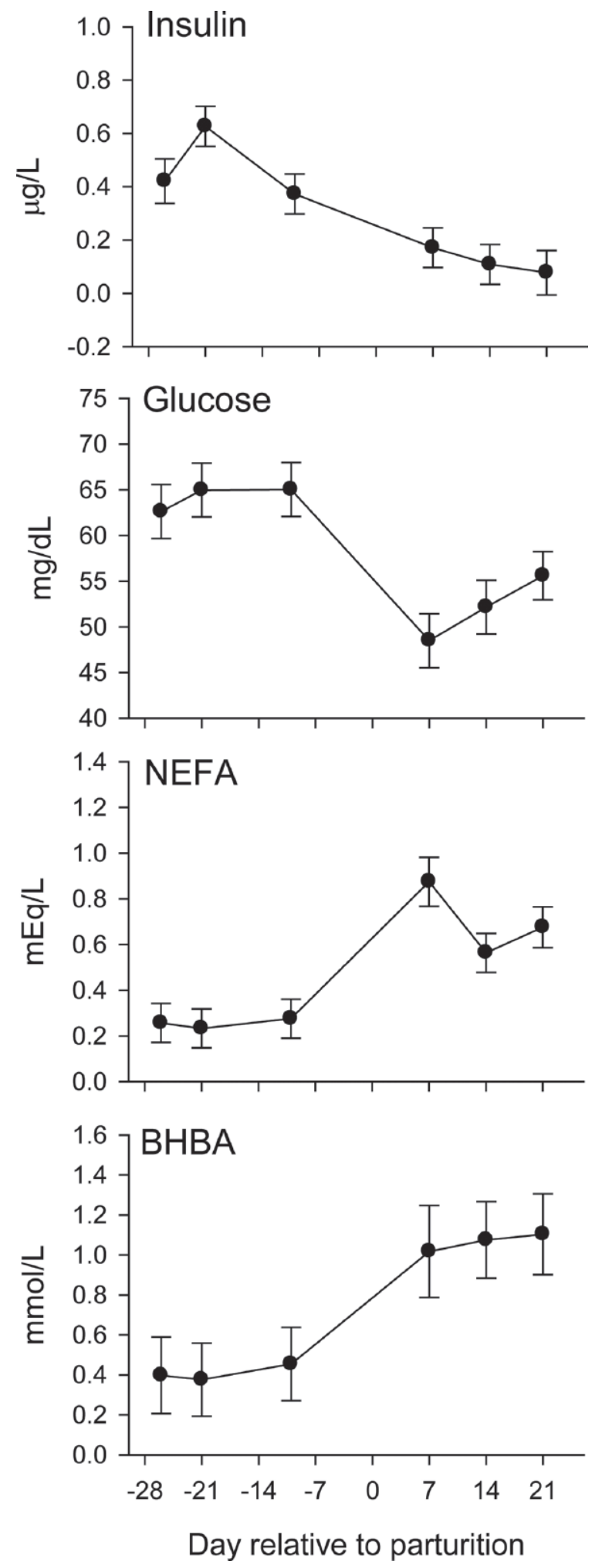

Figure 1. Profiles of insulin and metabolites in blood during the peripartal period. An overall time effect $(P<0.05)$ was observed for insulin and metabolites. For insulin and glucose, the concentration was lower $(P<0.05)$ during the postpartum period compared with prepartum. However, for NEFA and BHBA, the concentration was higher $(P<0.05)$ during the postpartum period compared with prepartum.

\section{ATP Release and Extracellular ATP Degradation}

The expression of gap junction protein $\alpha 1,43 \mathrm{kDa}$ (GJA1) and ectonucleotide pyrophosphatase/phosphodiesterase 1 (ENPP1) after parturition did not differ $(P>0.05)$ compared with d -10 (Table 1$)$. The expression of PANX1 and solute carrier family 29 (nucleoside transporters), member 2 (SLC29A2) was higher $(P<0.01$ and $P<0.05$, respectively) on d 3 compared with d -10 and 21 (Figure 5; Table 1). Among the purinergic receptors studied, this gene had the greatest percentage abundance (Supplemental Figure S1, available online at http://dx.doi.org/10.3168/ jds.2013-6952). Postpartal mRNA expression of solute carrier family 17, member 9 (SLC17A9) and solute carrier family 29 (nucleoside transporters), member 1 (SLC29A1) was greater $(P<0.01)$ compared with prepartal expression (Table 1). Higher mRNA expression of $A D A$ at 3 and $21 \mathrm{~d}$ and ectonucleoside triphosphate diphosphohydrolase 1 (ENTPD1) at d 21 was observed compared with d $-10(P<0.01$; Figure 5$)$.

\section{DISCUSSION}

\section{Cell Adhesion and Transmigration}

Endothelial cells are stimulated to produce adhesion molecules (i.e., P-selectins and E-selectins), not only by bacterial LPS and $N$-formyl-methionyl-leucylphenylalanine (fMLP) but classical cytokines such as IL-1 $\beta$, IL-17, and tumor necrosis factor $\alpha$ (Borregaard, 2010). Polymorphonuclear neutrophilic leukocytes express selectin $\mathrm{P}$ and L-selectin, which can bind to adhesion molecules located on the surface of endothelial cells near the inflamed tissues (Kansas, 1996). After selectins allow for binding between PMNL and endothelial cells, the PMNL express $\beta 2$-integrins, which can interact with intercellular adhesion molecules, thereby attaching more firmly with endothelial cells (Engelhardt and Wolburg, 2004).

The lower SELPLG and SELL expression that we observed after parturition suggested that the ability for cell adhesion in PMNL might have been reduced, a response of particular importance because SELL had the greatest percentage abundance among the genes measured (Supplemental Figure S1, available online at http://dx.doi.org/10.3168/jds.2013-6952). Lee and Kehrli (1998) reported that the expression of SELL in bovine PMNL was reduced after parturition and subsequent studies have proposed that this is due to elevated concentrations of cortisol (Burton et al., 1995; Weber et al., 2001) coupled with lower mRNA expression of the glucocorticoid receptor in PMNL (Preisler et al., 2000). Recent in vitro data also demonstrated 


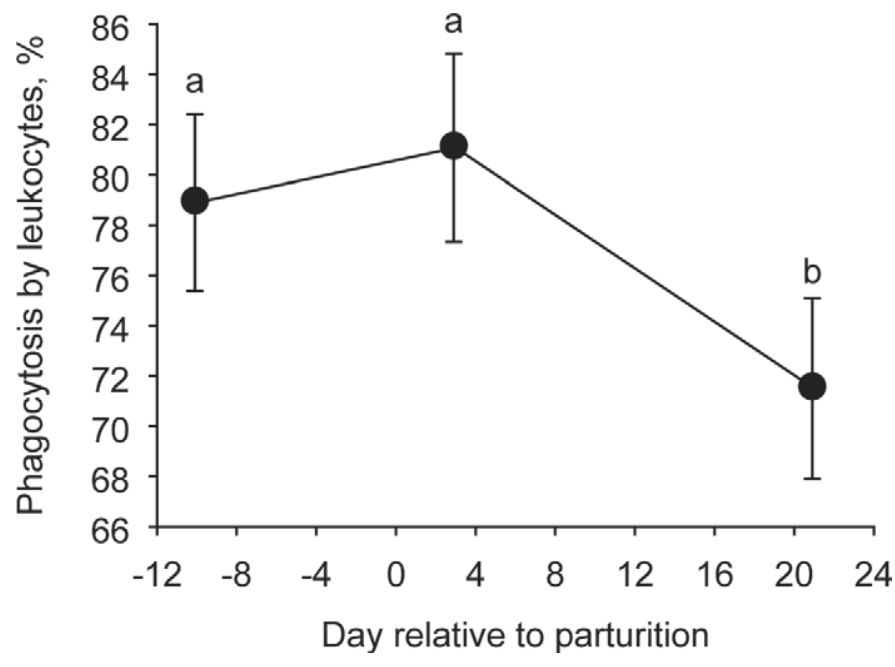

Figure 2. Phagocytosis by leukocytes in whole blood during the peripartal period. Different letters ( $\mathrm{a}$ and $\mathrm{b})$ denote differences $(P<$ 0.01) between time points.

that dexamethasone (a synthetic glucocorticoid) was necessary for ATP to elicit a proinflammatory response in endothelial cells (Ding et al., 2010). The fact that we did not observe a decrease in whole-blood leukocyte phagocytosis between $\mathrm{d}-10$ and 3 , which is similar to the response with PMNL observed by Sander et al. (2011) and Graugnard et al. (2012), suggests that any negative effect of cortisol on SELL and SELPLG might have been counteracted by a proinflammatory effect of ATP on the PMNL population, hence maintaining the ability of leukocytes to phagocytose.

Directed migration to inflammatory sites also is an important role of PMNL. After binding to the endothelium, the presence of receptors on PMNL (i.e., fMLP) and chemoattractants [i.e., complement fragment 5a (C5a), IL-8, platelet-activating factor (PTAF), and leukotriene B4 (LTB4)] allow the cells to follow the high concentrations of chemoattractants (Junger, 2008). The reduction in expression soon after calving of 4 receptors (C5AR1, CXCR1, CXCR2, and PTAFR) related to chemotaxis suggests that the transport of PMNL to inflammatory sites after parturition might have been impaired. Madsen et al. (2004) reported that the expression of IL-8 in bovine PMNL increased at parturition but they did not investigate the expression of IL-8 receptors. Our results suggest that upregulation of chemoattractants alone after calving is not strictly associated with upregulation of their functional receptors in PMNL. As a result of downregulation of chemotaxis receptors in PMNL, other mechanisms (e.g., increased ATP production and release) might be necessary to maintain PMNL function.

\section{Purinergic Receptors}

Recently, several studies reported that chemotaxis in PMNL is regulated through autocrine and paracrine pathways by extracellular ATP and its metabolites, such as adenosine, and the interaction with purine receptors (Haskó et al., 2008; Lazarowski, 2012). Purinergic receptors are composed of $\mathrm{P} 1$ adenosine receptors and P2 nucleotide receptors. The $\mathrm{P} 2$ receptors are separated into 2 subfamilies that are termed $\mathrm{P} 2 \mathrm{X}$ and $\mathrm{P} 2 \mathrm{Y}$ receptors (Ralevic and Burnstock, 1998). The P1 receptors are $\mathrm{G}$ protein-coupled receptors and are divided into A1 (ADORA1), A2a (ADORA2A), A2b (ADORA2B), and A3 (ADORA3; Ralevic and Burnstock, 1998). In this study, we evaluated the 3 adenosine receptors (ADORA1, ADORA2A, and ADORA3) and 3 ATP

Table 1. Expression patterns of genes associated with purinergic signaling, migration, and adhesion of PMNL during the peripartal period

\begin{tabular}{lllllr}
\hline & \multicolumn{3}{c}{ Day relative to parturition } & & \\
\cline { 2 - 4 } Gene $^{1}$ & -10 & 3 & 21 & SEM & $P$-value \\
\hline ITGB & $0.98^{\mathrm{ab}}$ & $1.11^{\mathrm{a}}$ & $0.93^{\mathrm{b}}$ & 0.05 & 0.03 \\
C5AR1 & $1.21^{\mathrm{a}}$ & $0.79^{\mathrm{b}}$ & $1.05^{\mathrm{a}}$ & 0.06 & $<0.01$ \\
CXCR1 & $1.05^{\mathrm{a}}$ & $0.65^{\mathrm{b}}$ & $0.92^{\mathrm{a}}$ & 0.05 & $<0.01$ \\
CXCR2 & $1.07^{\mathrm{a}}$ & $0.66^{\mathrm{b}}$ & $0.94^{\mathrm{a}}$ & 0.05 & $<0.01$ \\
LTB4R & $0.59^{\mathrm{b}}$ & $1.18^{\mathrm{a}}$ & $0.91^{\mathrm{a}}$ & 0.11 & $<0.01$ \\
GJA1 & 3.00 & 2.62 & 1.11 & 1.41 & 0.54 \\
SLC17A9 & $0.76^{\mathrm{c}}$ & $1.41^{\mathrm{a}}$ & $1.07^{\mathrm{b}}$ & 0.17 & $<0.01$ \\
SLC29A1 & $0.69^{\mathrm{c}}$ & $1.58^{\mathrm{a}}$ & $1.11^{\mathrm{b}}$ & 0.14 & $<0.01$ \\
SLC29A2 & $0.81^{\mathrm{b}}$ & $1.22^{\mathrm{a}}$ & $0.87^{\mathrm{b}}$ & 0.13 & 0.09 \\
ENPP1 & 1.17 & 1.03 & 1.28 & 0.15 & 0.08 \\
\hline
\end{tabular}

${ }^{a-c}$ Means within a row with different superscript letters indicate differences between days $(P<0.05)$.

${ }^{1} I T G B=\beta$ integrin; $C 5 A R 1=$ complement component 5 a receptor $1 ; C X C R 1=\mathrm{IL}-8$ receptor $\alpha ; C X C R 2=$ IL-8 receptor $\beta ; L T B 4 R=$ leukotriene B4 receptor; GJA1 = gap junction protein $\alpha 1,43 \mathrm{kDa}$; SLC17A9= solute carrier family 17 , member $9 ; S L C 29 A 1=$ solute carrier family 29 (nucleoside transporters), member 1 ; $S L C 29 A 2=$ solute carrier family 29 (nucleoside transporters), member 2; ENPP1 = ectonucleotide pyrophosphatase/phosphodiesterase 1 . 

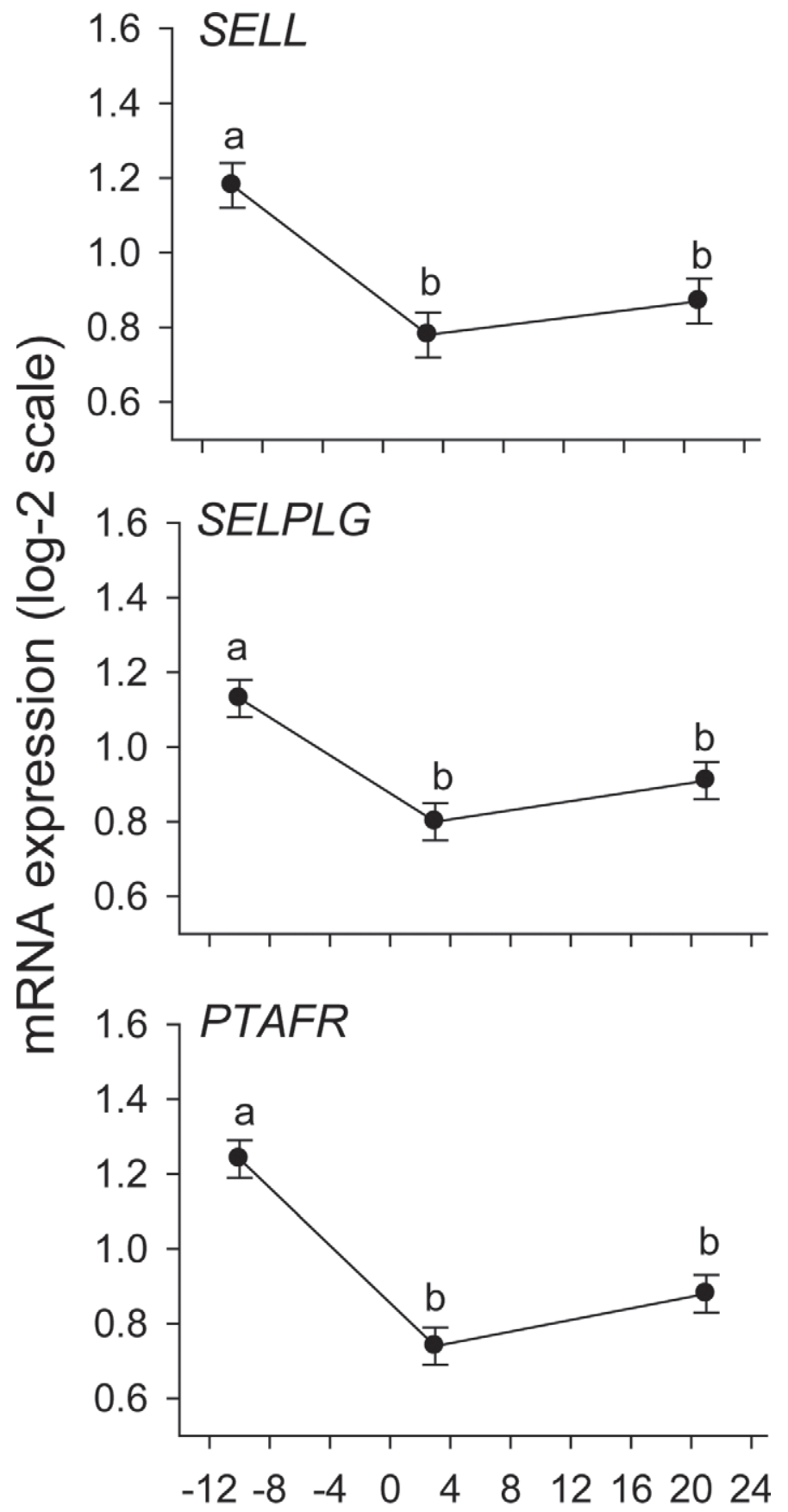

Day relative to parturition

Figure 3. Expression profile of genes associated with cell adhesion and leukocyte trafficking in blood PMNL harvested during the peripartal period. Different letters (a and b) denote differences $(P<$ 0.05) between times.

receptors (P2RX\%, P2RY2, and P2RY11). Among the selected P2 receptors, P2RX7 and P2RY11 are specific for ATP and P2RY2 has a greater binding affinity for ATP than uridine triphosphate (Junger, 2011). The interaction between $\mathrm{P} 2$ receptors and extracellular ATP is a crucial regulatory mechanism driving chemotaxis in PMNL (Corriden and Insel, 2012).

The PMNL release ATP through an autocrine mechanism when activated by chemoattractants. The key during this process is that ATP is released where the chemoattractants are recognized, thus suggesting that ATP accumulates near the cell surface (Junger, 2011). The ATP released from PMNL activates P2Y2 receptors, which amplify the chemotactic signals. Chen et al. (2006) demonstrated that ATP was released at the leading edge of the human PMNL surface; thus, it can have a synergistic effect with chemotactic signals. The P2Y2 receptors activated by ATP promoted the directed migration following the chemotactic gradient (Chen et al., 2006; Corriden and Insel, 2012). In a mouse model of sepsis, mice with inhibited P2Y2 receptors had lower neutrophil infiltration to the lung than wild types, suggesting that these receptors are part of the mechanism that allow PMNL to migrate into the infected tissue (Inoue et al., 2008). Thus, the inhibition of P2RY2 and P2RY11 expression can lead to interruption of PMNL chemotaxis, which might partly explain their increase in expression between $\mathrm{d}-10$ and 3 (Figure 4) and also the lack of decrease in leukocyte phagocytosis (Figure 2).

In addition to P2Y2 receptors, adenosine A3 receptors are also important receptors for chemotaxis in PMNL. Once ATP is released, a variety of extracellular nucleotidases join to hydrolyze ATP to adenosine. Subsequently, adenosine synthesized from extracellular ATP activates adenosine A3 receptors to translocate to the cell surface where chemoattractants are abundant and promotes directed migration toward infected cells (Chen et al., 2006; Junger, 2011; Barletta et al., 2012). In mice, blocking ADORA receptors or ablating expression of the gene resulted in significantly lower motility of PMNL but the ability of detecting chemoattractants was not affected (Junger, 2008). Adenosine A1 receptors also are associated with chemotaxis, adhesion, and phagocytosis (Barletta et al., 2012). The stimulation of A1 receptors by $\mathrm{N}^{6}$-cyclopentyladenosine promoted PMNL chemotaxis (Cronstein et al., 1990). In contrast to $\mathrm{A} 1$ and $\mathrm{A} 3$ receptors, adenosine $\mathrm{A} 2 \mathrm{a}$ receptors inhibit PMNL chemotaxis (Koizumi et al., 2009). The increase in ADORA2A expression coupled with the decrease of ADORA1 and ADORA3 between $\mathrm{d}-10$ and 3 provide additional evidence that the chemotactic ability of PMNL might have been lower after calving despite the upregulation of the P2Y2 receptor.

\section{ATP Release and Extracellular Degradation}

The expression of GJA1, PANX1, and SLC17A9 was studied because these genes are associated with ATP 

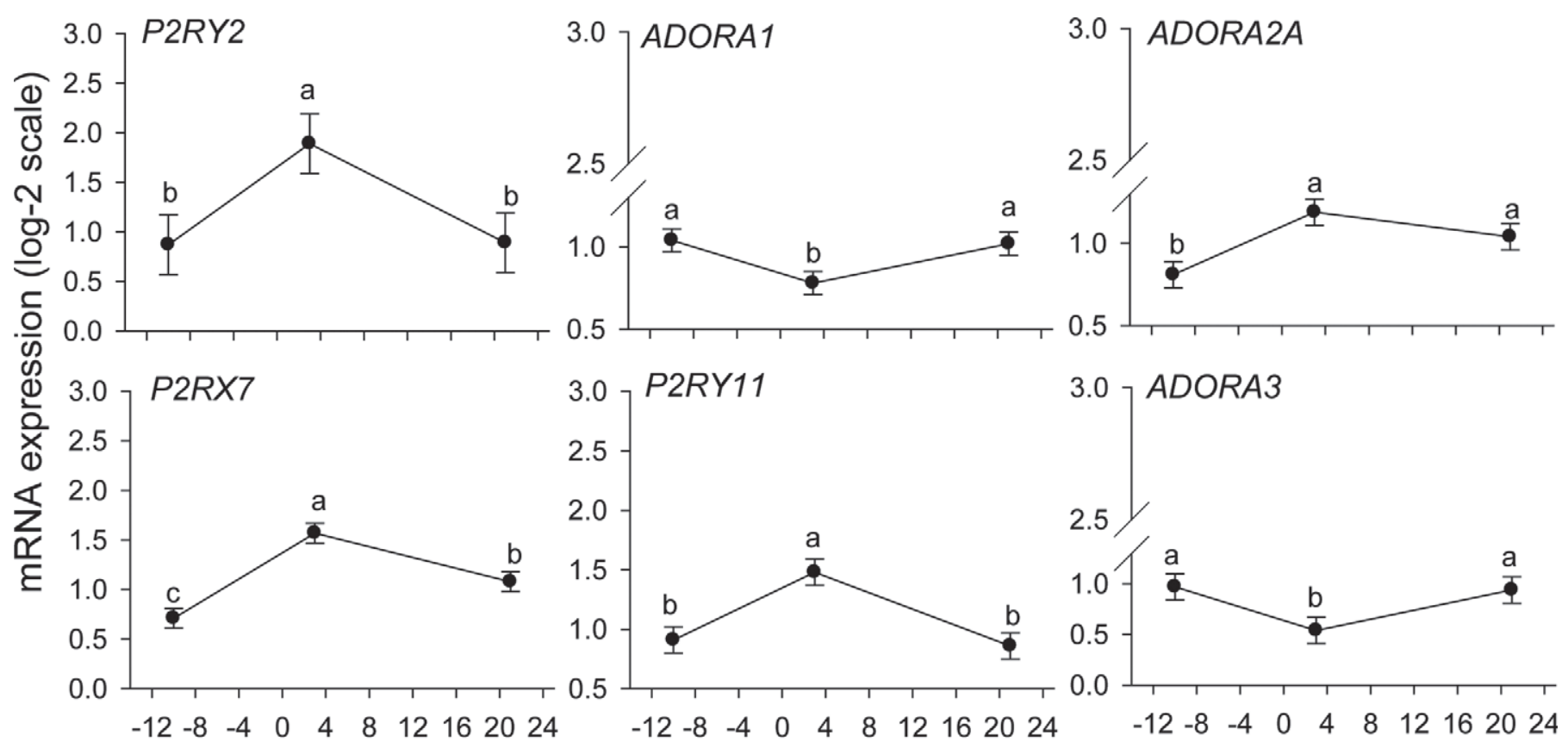

Day relative to parturition

Figure 4. Expression profile of purinergic signaling genes and adenosine receptors in blood PMNL harvested during the peripartal period. Different letters $(\mathrm{a}-\mathrm{c})$ denote differences $(P<0.05)$ between times. P2RY2 = purinergic receptor P2Y, G-protein coupled, 2; ADORA1 $=$ adenosine A1 receptor; $A D O R A 2 A=$ adenosine A2a receptor; $P 2 R X 7=$ purinergic receptor $\mathrm{P} 2 \mathrm{X}$ ligand-gated ion channel, $7 ; P 2 R Y 11=$ purinergic receptor P2Y G-protein coupled, 11; ADORA3 = adenosine A3 receptor.

release from PMNL (Junger, 2011). The upregulation of PANX1 and SLC17A9 after parturition suggested that the release of ATP from PMNL was not impaired in response to the activation of chemoattractant receptors. The main channel protein for ATP release in murine PMNL is connexin 43, which is encoded by GJA1 (Eltzschig et al., 2006), but our results revealed that PANX1 (Supplemental Figure S1, available online at http://dx.doi.org/10.3168/jds.2013-6952) is substantially more abundant than GJA1 in bovine PMNL. A greater degree of PMNL apoptosis caused by the elevated NEFA concentration (Figure 1) on d 3 compared with $\mathrm{d}-10$ also could have been a reason for the marked upregulation of PANX1. This idea is supported by recent in vitro studies demonstrating a causal link between elevated long-chain FA, apoptosis, and ATP release, which was blocked in large part when PANX1 expression was knocked down (Xiao et al., 2012).

The ATP released from PMNL via PANX1, for example, is rapidly converted to adenosine by several ectonucleotidases, which include those of the ENTPD family, ENPP family, alkaline phosphatases, and ectonucleotidase (CD73; Zimmermann, 1994; Robson et al., 2006). Chen et al. (2006) suggested that ENTPD plays a role in the conversion of ATP to adenosine, subsequently inducing the activation of adenosine A3 receptors and amplifying the chemotactic signal in human PMNL.

Adenosine deaminase is required to convert adenosine to inosine (Franco et al., 1998; Cristalli et al., 2001) and enzymatic deficiency of $A D A$ could induce the suppression of the immune response because high adenosine concentration (due to low $A D A$ activity) leads to excessive stimulation of adenosine A2a receptors (Apasov and Sitkovsky, 1999; Franco et al., 2007). Adenosine converted from extracellular ATP is transported into the cell through the nucleoside transporter encoded by SLC29A 1 to 4 (Baldwin et al., 2004).

In the current study, the sharp increase in expression of the ENT family (SLC29A1 and SLC29A2) and $A D A$ soon after parturition and the greater expression through d 21 suggests that there was abundant extracellular adenosine. This idea is supported by the almost 2 -fold increase in ADORA2A expression between $\mathrm{d}$ -10 and 3 and the lower expression of ADORA1 and ADORA3. Under such a scenario, it could be possible that prolonged exposure to elevated concentration of adenosine might have caused ADORA desensitization. The adenosine A2a receptors have a lower affinity for adenosine than A1 or A3 receptors (Barletta et al., 2012). Hence, this feature could lead to greater activation of $\mathrm{A} 2 \mathrm{a}$ receptors, rather than $\mathrm{A} 1$ or $\mathrm{A} 3$ receptors, 

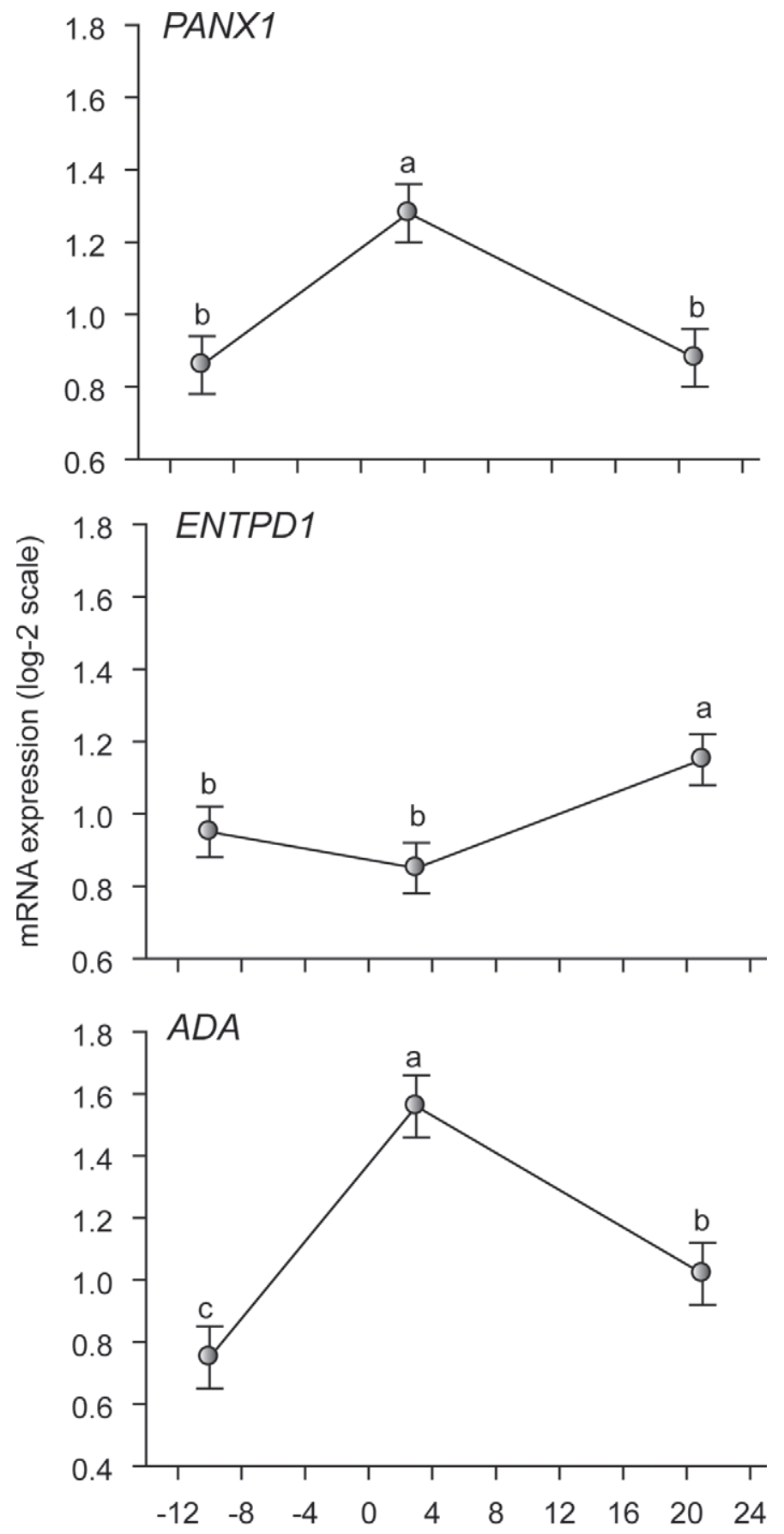

Day relative to parturition

Figure 5. Expression profile of genes associated with ATP hydrolysis [ectonucleoside triphosphate diphosphohydrolase 1 (ENTPD1)], adenosine hydrolysis [adenosine deaminase $(A D A)$ ], and ATP release [pannexin 1 (PANX1)] in blood PMNL harvested during the peripartal period. Different letters $(\mathrm{a}-\mathrm{c})$ denote differences $(P<0.05)$ between times. when adenosine concentration is increased. In humans, adenosine takes part in the inhibition of cell adhesion to the endothelium and also expression of ITGB on the PMNL surface (Thiel et al., 1996). However, it remains to be determined if adenosine alone could influence the function of PMNL during the peripartal period.

\section{CONCLUSIONS}

The changes in phagocytosis observed around calving appeared related, at least in part, to alterations in purinergic signaling as well as changes in expression of genes associated with adhesion and chemoattractant binding. Furthermore, data suggested that adenosine concentration might be increased at parturition, thereby contributing to the control of PMNL function. As in monogastrics, the data revealed that purinergic signaling plays an important role in the functions carried out by PMNL around parturition.

\section{REFERENCES}

Amulic, B., C. Cazalet, G. L. Hayes, K. D. Metzler, and A. Zychlinsky. 2012. Neutrophil function: From mechanisms to disease. Annu. Rev. Immunol. 30:459-489.

Apasov, S. G., and M. V. Sitkovsky. 1999. The extracellular versus intracellular mechanisms of inhibition of TCR-triggered activation in thymocytes by adenosine under conditions of inhibited adenosine deaminase. Int. Immunol. 11:179-189.

Baldwin, S. A., P. R. Beal, S. Y. M. Yao, A. E. King, C. E. Cass, and J. D. Young. 2004. The equilibrative nucleoside transporter family, SLC29. Pflugers Arch. 447:735-743.

Ballou, M. A. 2012. Immune responses of Holstein and Jersey calves during the preweaning and immediate postweaned periods when fed varying planes of milk replacer. J. Dairy Sci. 95:7319-7330.

Barletta, K. E., K. Ley, and B. Mehrad. 2012. Regulation of neutrophil function by adenosine. Arterioscler. Thromb. Vasc. Biol. $32: 856-864$

Bionaz, M., and J. J. Loor. 2008. Gene networks driving bovine milk fat synthesis during the lactation cycle. BMC Genomics 9:366.

Borregaard, N. 2010. Neutrophils, from marrow to microbes. Immunity 33:657-670.

Burton, J. L., M. E. Kehrli Jr., S. Kapil, and R. L. Horst. 1995. Regulation of L-selectin and CD18 on bovine neutrophils by glucocorticoids: Effects of cortisol and dexamethasone. J. Leukoc. Biol. 57:317-325.

Chen, Y., R. Corriden, Y. Inoue, L. Yip, N. Hashiguchi, A. Zinkernagel, V. Nizet, P. A. Insel, and W. G. Junger. 2006. ATP release guides neutrophil chemotaxis via P2Y2 and A3 receptors. Science 314:1792-1795.

Chen, Y., Y. Yao, Y. Sumi, A. Li, U. K. To, A. Elkhal, Y. Inoue, T. Woehrle, Q. Zhang, C. Hauser, and W. G. Junger. 2010. Purinergic signaling: A fundamental mechanism in neutrophil activation. Sci. Signal. 3:ra45

Corriden, R., and P. A. Insel. 2012. New insights regarding the regulation of chemotaxis by nucleotides, adenosine, and their receptors. Purinergic Signal. 8:587-598.

Cristalli, G., S. Costanzi, C. Lambertucci, G. Lupidi, S. Vittori, R Volpini, and E. Camaioni. 2001. Adenosine deaminase: Functional implications and different classes of inhibitors. Med. Res. Rev. $21: 105-128$.

Cronstein, B. N., L. Daguma, D. Nichols, A. J. Hutchison, and M. Williams. 1990. The adenosine/neutrophil paradox resolved: Human neutrophils possess both $\mathrm{A} 1$ and $\mathrm{A} 2$ receptors that promote 
chemotaxis and inhibit $\mathrm{O}_{2}$ generation, respectively. J. Clin. Invest. 85:1150-1157.

D' Ambrosi, N., and C. Volonte. 2013. Metabotropic purinergic receptors in lipid membrane microdomains. Curr. Med. Chem. 20:56-63.

Ding, Y., Z.-G. Gao, K. A. Jacobson, and A. F. Suffredini. 2010. Dexamethasone enhances ATP-induced inflammatory responses in endothelial cells. J. Pharmacol. Exp. Ther. 335:693-702.

Dosogne, H., C. Burvenich, A. E. Freeman, M. E. Kehrli Jr., J. C. Detilleux, J. Sulon, J. F. Beckers, and D. Hoeben. 1999. Pregnancy-associated glycoprotein and decreased polymorphonuclear leukocyte function in early post-partum dairy cows. Vet. Immunol. Immunopathol. 67:47-54.

Eltzschig, H. K., T. Eckle, A. Mager, N. Küper, C. Karcher, T. Weissmüller, K. Boengler, R. Schulz, S. C. Robson, and S. P. Colgan. 2006. ATP release from activated neutrophils occurs via connexin 43 and modulates adenosine-dependent endothelial cell function. Circ. Res. 99:1100-1108.

Engelhardt, B., and H. Wolburg. 2004. Mini-review: Transendothelial migration of leukocytes: Through the front door or around the side of the house? Eur. J. Immunol. 34:2955-2963.

Franco, R., R. Pacheco, J. M. Gatell, T. Gallart, and C. Lluis. 2007. Enzymatic and extraenzymatic role of adenosine deaminase 1 in T-cell-dendritic cell contacts and in alterations of the immune function. Crit. Rev. Immunol. 27:495-509.

Franco, R., A. Valenzuela, C. Lluis, and J. Blanco. 1998. Enzymatic and extraenzymatic role of ecto-adenosine deaminase in lymphocytes. Immunol. Rev. 161:27-42.

Graugnard, D. E., M. Bionaz, E. Trevisi, K. M. Moyes, J. L. SalakJohnson, R. L. Wallace, J. K. Drackley, G. Bertoni, and J. J. Loor. 2012. Blood immunometabolic indices and polymorphonuclear neutrophil function in peripartum dairy cows are altered by level of dietary energy prepartum. J. Dairy Sci. 95:1749-1758.

Haskó, G., J. Linden, B. Cronstein, and P. Pacher. 2008. Adenosine receptors: Therapeutic aspects for inflammatory and immune diseases. Nat. Rev. Drug Discov. 7:759-770.

Ingvartsen, K. L., R. J. Dewhurst, and N. C. Friggens. 2003. On the relationship between lactational performance and health: Is it yield or metabolic imbalance that cause production diseases in dairy cattle? A position paper. Livest. Prod. Sci. 83:277-308.

Inoue, Y., Y. Chen, M. I. Hirsh, L. Yip, and W. G. Junger. 2008. A3 and P2Y2 receptors control the recruitment of neutrophils to the lungs in a mouse model of sepsis. Shock 30:173-177.

Ishikawa, H., T. Shirahata, and K. Hasegawa. 1994. Interferon-gamma production of mitogen stimulated peripheral lymphocytes in perinatal cows. J. Vet. Med. Sci. 56:735-738.

Ji, P., J. S. Osorio, J. K. Drackley, and J. J. Loor. 2012. Overfeeding a moderate energy diet prepartum does not impair bovine subcutaneous adipose tissue insulin signal transduction and induces marked changes in peripartal gene network expression. J. Dairy Sci. 95:4333-4351.

Junger, W. G. 2008. Purinergic regulation of neutrophil chemotaxis. Cell. Mol. Life Sci. 65:2528-2540.

Junger, W. G. 2011. Immune cell regulation by autocrine purinergic signalling. Nat. Rev. Immunol. 11:201-212.

Kansas, G. S. 1996. Selectins and their ligands: Current concepts and controversies. Blood 88:3259-3287.

Kimura, K., J. P. Goff, and M. E. Kehrli Jr. 1999. Effects of the presence of the mammary gland on expression of neutrophil adhesion molecules and myeloperoxidase activity in periparturient dairy cows. J. Dairy Sci. 82:2385-2392.

Koizumi, S., M. Odashima, M. Otaka, M. Jin, J. Linden, S. Watanabe, and H. Ohnishi. 2009. Attenuation of gastric mucosal inflamma- tion induced by indomethacin through activation of the A2A adenosine receptor in rats. J. Gastroenterol. 44:419-425.

Lazarowski, E. R. 2012. Vesicular and conductive mechanisms of nucleotide release. Purinergic Signal. 8:359-373.

Lee, E. K., and M. E. Kehrli Jr. 1998. Expression of adhesion molecules on neutrophils of periparturient cows and neonatal calves. Am. J. Vet. Res. 59:37-43.

Madsen, S. A., L. C. Chang, M. C. Hickey, G. J. Rosa, P. M. Coussens, and J. L. Burton. 2004. Microarray analysis of gene expression in blood neutrophils of parturient cows. Physiol. Genomics $16: 212-221$.

Moyes, K. M., J. K. Drackley, D. E. Morin, and J. J. Loor. 2010. Greater expression of TLR2, TLR4, and IL6 due to negative energy balance is associated with lower expression of HLA-DRA and HLA-A in bovine blood neutrophils after intramammary mastitis challenge with Streptococcus uberis. Funct. Integr. Genomics 10:53-61.

Paape, M. J., D. D. Bannerman, X. Zhao, and J. W. Lee. 2003. The bovine neutrophil: Structure and function in blood and milk. Vet. Res. 34:597-627.

Paape, M. J., D. W. Carroll, A. J. Kral, R. H. Miller, and C. Desjardins. 1974. Corticosteroids, circulating leukocytes, and erythrocytes in cattle: Diurnal changes and effects of bacteriologic status, stage of lactation, and milk yield on response to adrenocorticotropin. Am. J. Vet. Res. 35:355-362.

Picher, M., L. H. Burch, and R. C. Boucher. 2004. Metabolism of P2 receptor agonists in human airways: Implications for mucociliary clearance and cystic fibrosis. J. Biol. Chem. 279:20234-20241.

Preisler, M. T., P. S. Weber, R. J. Tempelman, R. J. Erskine, H. Hunt, and J. L. Burton. 2000. Glucocorticoid receptor down-regulation in neutrophils of periparturient cows. Am. J. Vet. Res. 61:14-19.

Ralevic, V., and G. Burnstock. 1998. Receptors for purines and pyrimidines. Pharmacol. Rev. 50:413-492.

Robson, S. C., J. Sévigny, and H. Zimmermann. 2006. The E-NTPDase family of ectonucleotidases: Structure function relationships and pathophysiological significance. Purinergic Signal. 2:409-430.

Sander, A. K., M. Piechotta, G. Schlamberger, H. Bollwein, M. Kaske, A. Sipka, and H. J. Schuberth. 2011. Ex vivo phagocytic overall performance of neutrophilic granulocytes and the relation to plasma insulin-like growth factor-I concentrations in dairy cows during the transition period. J. Dairy Sci. 94:1762-1771.

Sordillo, L. M., and L. A. Babiuk. 1991. Modulation of bovine mammary neutrophil function during the periparturient period following in vitro exposure to recombinant bovine interferon gamma. Vet. Immunol. Immunopathol. 27:393-402.

Thiel, M., J. D. Chambers, A. Chouker, S. Fischer, C. Zourelidis, H. J. Bardenheuer, K.-E. Arfors, and K. Peter. 1996. Effect of adenosine on the expression of $\beta_{2}$ integrins and L-selectin of human polymorphonuclear leukocytes in vitro. J. Leukoc. Biol. 59:671-682.

Trevisi, E., A. Zecconi, G. Bertoni, and R. Piccinini. 2010. Blood and milk immune and inflammatory profiles in periparturient dairy cows showing a different liver activity index. J. Dairy Res. $77: 310-317$.

Weber, P. S., S. A. Madsen, G. W. Smith, J. J. Ireland, and J. L. Burton. 2001. Pre-translational regulation of neutrophil L-selectin in glucocorticoid-challenged cattle. Vet. Immunol. Immunopathol. 83:213-240.

Xiao, F., S. L. Waldrop, A. Khimji, and G. Kilic. 2012. Pannexin1 contributes to pathophysiological ATP release in lipoapoptosis induced by saturated free fatty acids in liver cells. Am. J. Physiol. Cell Physiol. 303:C1034-C1044.

Zimmermann, H. 1994. Signalling via ATP in the nervous system. Trends Neurosci. 17:420-426. 